\title{
A STUDY OF THE TIME NECESSARY FOR CALCIUM HYDROXIDE TO ELIMINATE MICROORGANISMS IN INFECTED CANALS
}

\author{
ESTUDO DO TEMPO NECESSÁRIO PARA O HIDRÓXIDO DE CÁLCIO \\ ELIMINAR MICRORGANISMOS EM CANAIS INFECTADOS
}

\author{
Carlos ESTRELA, DDS, MSc, PhD \\ Chairman and Professor of Endodontics, Federal University of Goiás, Goiânia, GO, Brazil. \\ Cyntia Rodrigues de Araújo ESTRELA, DDS, MSc \\ Dentistry Center of State Health Secretary, Goiânia, GO, Brazil. \\ Jesus Djalma PÉCORA, DDS, MSc, PhD \\ Chairman and Professor of Endodontics, University of São Paulo, Ribeirão Preto, São Paulo, SP, Brazil.
}

\begin{abstract}
$T$ he objective of this study was to analyze the time necessary for calcium hydroxide to eliminate microorganisms in infected canals. A total of 168 human anterior teeth were prepared and sterilized. One hundred sixty two teeth were inoculated with suspensions of $S$. aureus, E. faecalis, P. aeruginosa, B. subtilis, C. albicans. Three teeth were used as negative control and three as positive control. Root canals were irrigated with saline and filled with calcium hydroxide paste (CHP). At intervals of 1 minute, and at 7, 15, 21, 27, 30, 45, 60, and 90 days, CHP was removed, samples were collected and immersed in Letheen Broth (LB). Microbial growth was analyzed by two methods, turbidity of the culture medium and subculture on a Brain heart Infusion. After looking for medium change, an inoculum of $0.1 \mathrm{~mL}$ obtained from LB was transferred to $7 \mathrm{~mL}$ of Brain Heart Infusion (BHI), and subsequently incubated at $37^{\circ} \mathrm{C}$ for 48 hours. Microbial growth was checked by turbidity of the culture medium and in some cases by Gram stain. All assays were carried out in triplicate under aseptic technique. The results indicated that the antimicrobial effect on the cultures of S. aureus, E. faecalis, P. aeruginosa, B. subtilis, C. albicans and one mixed culture in infected canals by CHP occurred in 60 days.
\end{abstract}

UNITERMS: Calcium hydroxide; Dental pulp cavity, microbiology.

\section{INTRODUCTION}

The determination and knowledge of the endodontic microbiota are essential for effective microbial control. Eubacterium, Peptococcus, Peptostreptococcus, Prevotella, Porphyromonas and Fusobacterium are predominant microorganisms in infected root canals ${ }^{17,13}$. Endodontic infection resistance has been associated with facultative bacteria. E. faecalis has a pathogenic role in chronic endodontic treatment failure ${ }^{12}$.

It is established that viable bacteria can be recovered from the root canal after it has been treated by effective disinfection process and root canal preparation ${ }^{1}$. Therefore, effective antimicrobial control requires the use of an intracanal dressing.
Calcium hydroxide has antimicrobial effectiveness against microorganisms found in root canal infections. Its antimicrobial mechanism of action involves the speed of dissociation into calcium and hydroxyl ions in a high $\mathrm{pH}$ (12.6) environment that inhibits enzymatic activities - metabolism, growth and cellular division essential to microbial life. It can change the integrity of the cytoplasmic membrane by means of chemical injuries to organic components and transport of nutrients, or by means of destruction of phospholipids or unsaturated fatty acids of the cytoplasmic membrane, observed in the lipidic peroxidation process, which is a saponification reaction ${ }^{5}$.

Considering that the release of hydroxyl ions from calcium hydroxide is essential to the microbial control process, it is important to use vehicles that favor rapid 
ionic dissociation and, in addition, maintain a high $\mathrm{pH}$ during the entire period of activity. The chemical characteristics of vehicles - i.e., whether they are hydrosoluble or oily, together with their ionic dissociation and diffusion capability, conductivity and $\mathrm{pH}$ - may be more important than the antimicrobial action of the vehicle.

Estrela et al. ${ }^{2}$ studied the effect of several vehicles (saline solution, camphorated paramonochlorophenol [CMCP], chlorhexidine solution, sodium lauryl sulphate, Otosporin ${ }^{\circledR}$ ) on the antimicrobial efficiency of calcium hydroxide acting in direct exposure test. The antimicrobial effect occurred after 48 hours on all pure and mixed suspensions of microorganisms. The vehicles used with calcium hydroxide did not affect the time required for microbial inactivation.

The control of microorganisms by calcium hydroxide is determined by the liberation of hydroxyl ions, which requires an ideal length of time for effective microbial destruction ${ }^{6-8}$. The liberation of hydroxyl ions to attain the high $\mathrm{pH}$ that may completely eliminate the microorganisms can be delayed ${ }^{9,20}$. However, the time necessary for calcium hydroxide to express its control on microorganisms resistant to antimicrobial substances has not been determined yet.

The purpose of this study was to determine the length of time for calcium hydroxide to control microorganisms in infected canals.

\section{MATERIAL AND METHODS}

\section{Test organisms}

Five reference microbial strains - Staphylococcus aureus (ATCC 6538), Enterococcus faecalis (ATCC 29212), Pseudomonas aeruginosa (ATCC 27853), Bacillus subtilis (ATCC 6633) and Candida albicans (ATCC 10231) - obtained from American Type Culture Collection were included in the study.

The strains were inoculated in $7 \mathrm{~mL}$ of Brain Heart Infusion (BHI; Difco Laboratories, Detroit, MI, USA) and incubated at $37^{\circ} \mathrm{C}$ for $24 \mathrm{~h}$. To prepare the experimental suspensions, the biological indicators were cultivated on the surface of Brain Heart Infusion Agar (BHIA; Difco Laboratories, Detroit, MI, USA), following the same incubation conditions; microbial cells were resuspended in saline to give a final concentration of about $3 \times 10^{8}$ cells $/ \mathrm{mL}$, similar to that of tube No. 1 of the MacFarland scale. One $\mathrm{mL}$ of each of these pure suspensions was used to obtain a mixture of the test microorganisms.

\section{Testing antimicrobial action}

One hundred and sixty-eight human anterior teeth from a teeth bank of the endodontic research laboratory extracted for different reasons were used for this study. The apical foramen was closed with composite resin to reduce possible contamination of the external surface. Teeth were prepared up to size ISO 50 (Kfile, Maillefer, Switzerland) $1 \mathrm{~mm}$ before the apical foramen, using a step-back preparation technique. The cervical third was enlarged with \#3 and \#4 GatesGlidden burs. Three millilitres of $1 \%$ sodium hypochlorite was used for irrigation after each file while instrumenting the root canals. Root canals were dried and filled with 17\% EDTA (pH 7.2) for 3 min. After cleaning and shaping of root canals teeth were sterilized by autoclaving for 30 minutes at $120^{\circ} \mathrm{C}$.

Six groups of 27 teeth each were inoculated with pure or mixed culture of biological indicators during 28 days, using syringes of sufficient volume to fill the root canal. This procedure was repeated every 72 hours, always using 24-hour cultures prepared and adjusted to tube \# 1 of MacFarland scale. Teeth were maintained in a humid environment at $37^{\circ} \mathrm{C}$. After that, root canals were irrigated with $5 \mathrm{~mL}$ of saline, dried with sterilized absorbent paper points, and completely filled with calcium hydroxide paste (CHP). The paste was prepared with calcium hydroxide P.A. (Quimis Mallinkrodt, Inc., St. Louis, MO, USA) and saline as vehicle. Viscosity of the paste was $3501 \mathrm{cP}-0.1 \mathrm{rpm}$ (Reometer Digital Brookfield, Model DV-III-IV, Philadelphia, PA, USA), corresponding to the consistency of toothpaste, with $\mathrm{pH} 12.6$ determined by a $\mathrm{pH}$ meter (Analion, $\mathrm{pH}$ digital, PM 605, Philadelphia, PA, USA).

At intervals of 1 minute, 7, 15, 21, 27, 30, 45, 60, and 90 days, CHP was removed from three teeth from each group using saline and mechanical stirring with files. Subsequently, root canals were dried and filled with sterile saline solution. Each sample was collected by using three paper points (Tanari, Tanariman Indústria, Ltda., Manacaru, AM, Brazil), individually transported and immersed in $7 \mathrm{~mL}$ of Letheen Broth (LB; Difco Laboratories, Detroit, MI, USA), followed by incubation at $37^{\circ} \mathrm{C}$ for $48 \mathrm{~h}$.

Microbial growth was analyzed by two methods, turbidity of the culture medium and subculture on a specific nutrient broth, since the tested medication caused culture medium changes. Thus, after looking for $\mathrm{LB}$ changes, an inoculum of $0.1 \mathrm{~mL}$ obtained from the medium was transferred to $7 \mathrm{~mL}$ of $\mathrm{BHI}$, and subsequently incubated at $37^{\circ} \mathrm{C}$ for $48 \mathrm{~h}$. Microbial growth was checked by turbidity of the culture medium 
and in some cases by Gram stain. All assays were carried out in triplicate under aseptic techniques.

Two control groups with three teeth each were used, for testing sterility (negative control) and for checking microorganisms viability during the experimental periods (positive control). Thus, during 28 days of contamination of the root canals, three non-inoculated teeth were maintained in incubation at $37^{\circ} \mathrm{C}$, as an aseptic control; and three teeth were inoculated with the mixture of microorganisms and incubated under identical conditions. In each tooth of the control groups, in all the intervals of the experimental period, root canals were filled with sterile saline solution, and three samples were collected by using sterile paper points and transferred to $7 \mathrm{~mL}$ of $\mathrm{BHI}$ and incubated under identical conditions. Microbial growth was observed by turbidity of the culture medium.

\section{RESULTS}

The results indicated that the antimicrobial effect on the cultures of $\mathrm{S}$. aureus, E. faecalis, P. aeruginosa, B. subtilis, $C$. albicans and one mixed culture in infected canal by CHP occurred in 60 days (Table 1). In all the intervals of the experimental period, the microorganisms maintained viability, as shown by growth of positive controls up 90 days. The maintenance of a high concentration of hydroxyl ions can change enzymatic activity and promote its inactivation. It is necessary, whenever possible, to allow time for the CHP to manifest its potential action on the microorganisms present in endodontic infections.

\section{DISCUSSION}

The complete inhibition of microorganisms (S. aureus, E. faecalis, P. aeruginosa, B. subtilis, C. albicans and one mixed culture of these) by CHP in infected canal occurred at 60 days (Table 1). In this investigation saline solution was used as a root canal irrigant to avoid masking the antimicrobial potential of CHP.

CHP showed antimicrobial effect on S. aureus, E. faecalis, P. aeruginosa, B. subtilis, C. albicans and one mixed culture at periods ranging from $1 \mathrm{~min}$ to $72 \mathrm{~h}$ by direct exposure test ${ }^{2}$; calcium hydroxide had no positive antimicrobial activity during 7 days in infected canals with the same microorganisms described previously? ${ }^{7}$.

Some studies have established experimental models for root canal infection, and have allowed the observation of the depth of penetration of different microorganisms in canals as a function of the time of incubation, as well as the efficacy of endodontic dressings and irrigants ${ }^{10,14,15}$.

The contamination period of root canals in this study was 28 days, time enough for deep infection of the dentinal tubules to take place, as described previously ${ }^{10,14}$. In this context, the length of time required by calcium hydroxide to express microbial inactivation is determined by various factors, such as velocity of dissociation and diffusion of hydroxyl ions, greater or lesser dentinal permeability, and dentine buffering capacity. The release of hydroxyl ions affect the action of calcium hydroxide. Chemically, hydrosoluble vehicles (distilled water, saline solution)

TABLE 1- Time necessary for CHP paste to eliminate microorganisms in infected canals

\begin{tabular}{|c|c|c|c|c|c|c|c|c|c|}
\hline Microorganisms & $1 \mathrm{~min}$ & $7 \mathrm{~d}$ & $15 \mathrm{~d}$ & $21 \mathrm{~d}$ & $27 \mathrm{~d}$ & $30 \mathrm{~d}$ & $45 d$ & $60 \mathrm{~d}$ & $90 \mathrm{~d}$ \\
\hline S. aureus & +++ & +++ & +++ & +++ & +++ & +++ & +++ & -- & -- \\
\hline E. faecalis & +++ & +++ & +++ & +++ & +++ & +++ & +++ & --- & --- \\
\hline P. aeruginosa & +++ & +++ & +++ & +++ & +++ & +++ & +++ & -- & -- \\
\hline B. subitilis & +++ & +++ & +++ & +++ & +++ & +++ & +++ & $--\cdot$ & -- \\
\hline C.albicans & +++ & +++ & +++ & +++ & +++ & +++ & +++ & --- & -- \\
\hline Mixed & +++ & +++ & +++ & +++ & +++ & +++ & +++ & -- & -- \\
\hline Negative Control & -- & -- & -- & -- & - - & - - & $\ldots$ & -- & -- \\
\hline Positive Control & +++ & +++ & +++ & +++ & +++ & +++ & +++ & +++ & +++ \\
\hline
\end{tabular}

$(+++)$ : Presence of growth; $(---)$ : Absence of growth 
induce a higher speed of ionic dissociation than oily (CMCP) and viscous vehicles (polyethylene glycol). Hydrosoluble vehicles (distilled water or saline solution) accelerate ionic dissociation and diffusion of CHP, and interfere with the bacterial enzyme and tissue system ${ }^{3,4}$. Estrela, Pesce ${ }^{6}$ chemically analyzed the liberation of calcium and hydroxyl ions from CHP with vehicles of different acid-base and hydrosolubility characteristics by means of conductimeter analysis of their solutions in a sample of connective tissue from a dog. The liberation of hydroxyl ions from the CHP can be demonstrated by the liberation of calcium ions and hydroxyl ions and the molecular weight of calcium hydroxide. In $1 \mathrm{~mol}$ of dissociated calcium hydroxide, $45.89 \%$ are hydroxyl ions and $54.11 \%$ are calcium ions. The speed of ionic dissociation is determined by the vehicle and is more effective when hydrosoluble vehicles are used.

Sjögren, et al. ${ }^{16}$ studied the antimicrobial effect of calcium hydroxide as a short-term intracanal dressing in teeth with periapical lesion. They applied it for 10 minutes and for 7 days, and reported that the effective destruction of microorganisms was complete only after 1 week. Tronstad ${ }^{19}$ reported that the long-lasting antibacterial effect of CHP is highly dependent on a constant high alkalinity of the paste. Microorganism like E. faecalis may survive in an environment with a $\mathrm{pH}$ of up to 11. CHP in the apical part of the canal may have a $\mathrm{pH}$ of 8 within 2-3 weeks of placement. Sydney ${ }^{18}$ observed endodontic microbiota at different times after root canal preparation in teeth with asymptomatic apical periodontitis and after the use of CHP as intracanal dressing. The endodontic microbiota was reduced to $77.8 \%$ after 1 week, and E. faecalis was isolated in only one instance after 6 weeks. Han et al. ${ }^{11}$ studied "in vitro" antimicrobial activity of calcium hydroxide containing pastes (DT Temporary DressingÒ - $\mathrm{Ca}(\mathrm{OH})_{2}+$ distilled water; VitapexÒ - $\mathrm{Ca}(\mathrm{OH})_{2}+$ Iodoform + Silicone Oil + others) in human roots infected with $\mathrm{E}$. faecalis for 3 weeks. Medications were maintained in the canals for 7 days, when dentine chips were analyzed. The aqueous CHP was effective in the elimination of $\mathrm{E}$. faecalis in all groups except in the smeared group with oil-based calcium hydroxide (VitapexÒ). The differences between these results and those of this study may be explained by the different experimental methods used.

It is necessary, whenever possible, to allow time for the CHP to manifest its potential action on the microorganisms present in endodontic infections. The maintenance of a high concentration of hydroxyl ions can change enzymatic activity and promote its inactivation. The elimination of microorganisms by CHP in infected canal "in vitro" occurred in 60 days when saline solution was chosen as endodontic irrigant to avoid masking the antimicrobial potential of CHP. However, the endodontic irrigant can influence the microbial control positively. Further research must examine other variables to determine the ideal length of time for antimicrobial activity of calcium hydroxide in infected root canals with apical periodontitis.

\section{CONCLUSIONS}

The antimicrobial effect on the cultures of S. aureus, E. faecalis, P. aeruginosa, B. subtilis, C. albicans and one mixed culture in infected canals by CHP occurred in 60 days, length of time necessary for microbial inactivation, under the conditions of this study.

\section{ACKNOWLEDGMENTS}

We thank CNPq for the financial support for this research (CNPq n. 523384/95).

\section{RESUMO}

O objetivo deste estudo foi analisar o tempo necessário para que o hidróxido de cálcio elimine microrganismos em canais infectados. Um total de 168 dentes humanos anteriores foram preparados e esterilizados. Cento e sessenta e dois dentes foram inoculados com suspensões de S. aureus, E. faecalis, P. aeruginosa, B. subtilis e C. albicans. Três dentes foram usados como controle negativo e três como controle positivo. Os canais radiculares foram irrigados com solução fisiológica e preenchidos com pasta de hidróxido de cálcio. Em intervalos de 1 minuto, $7,15,21,27,30,45,60$ e 90 dias, a pasta foi removida, amostras foram coletadas e imersas em Letheen Broth. O crescimento microbiano foi analisado por dois métodos, turvação do meio de cultura e subcultura em caldo Brain Heart Infusion (BHI). Após alterações do Letheen Broth, um inóculo de $0,1 \mathrm{~mL}$ do meio foi transferido para $7 \mathrm{~mL}$ de BHI, e subseqüentemente incubado a $37^{\circ} \mathrm{C}$ for $48 \mathrm{~h}$. O crescimento microbiano foi analisado pela turvação do meio de cultura e em alguns casos pela coloração de Gram. Todos os ensaios foram feitos em triplicata, obedecendo a técnica asséptica. Os resultados indicaram que o efeito antimicrobiano, em culturas 
de S. aureus, E. faecalis, P. aeruginosa, B. subtilis, C. albicans e uma cultura mixta em canais infectados, ocorreu em 60 dias.

UNITERMOS: Hidróxido de cálcio; Cavidade da polpa dentária, microbiologia.

\section{REFERENCES}

1. Byström A, Sundqvist G. Bacteriologic evaluation of the efficacy of mechanical root canal instrumentation in endodontic therapy. Scand J Dent Res 1981; 89:321-8.

2. Estrela C, Bammann LL, Pimenta FC, Pecora JD. Control of microorganisms by calcium hydroxide pastes. Int Endod J 2001; $34: 341-5$

3. Estrela C, Estrela CRA, Bammann LL, Pécora JD. Two methods to evaluate the antimicrobial action of calcium hydroxide paste. $\mathrm{J}$ Endodon 2001; 27: 712-15.

4. Estrela C, Pécora JD, Sousa-Neto MD, Estrela CRA, Bammann LL. Effect of vehicle on antimicrobial properties of calcium hydroxide paste. Brazil Dent J 1999; 10: 63-72.

5. Estrela C, Sydney GB, Bammann LL, Felippe Jr O. Mechanism of action of calcium and hydroxyl ions of calcium hydroxide on tissue and bacteria. Brazil Dent J 1995; 6:85-90.

6. Estrela C, Pesce HF. Chemical analysis of the liberation of calcium and hydroxyl ions from calcium hydroxide pastes in connective tissue in dog. Part I. Brazil Dent J 1996; 7: 41-6.

7. Estrela C, Pimenta FC, Ito IY, Bammann LL. In vitro determination of direct antimicrobial effect of calcium hydroxide. J Endodon 1998; 24:15-7.

8. Estrela C, Pimenta FC, Ito IY, Bammann LL. Antimicrobial evaluation of calcium hydroxide in infected dentinal tubules. J Endodon 1999; 25:416-8.

9. Estrela C, Sydney GB, Pesce HF, Felippe Jr O. Dentinal diffusion of hydroxyl ions of various calcium hydroxide pastes. Brazil Dent J 1995; 6:5-9.

10. Haapasalo M, Ørstavik D. "In vitro" infection and disinfection of dentinal tubules. J Dent Res 1987; 6:1375-9.

11. Han GY, Park S-H, Yoon TC. Antimicrobial activity of $\mathrm{Ca}(\mathrm{OH})_{2}$ containing pastes with Enterococcus faecalis "in vitro". J Endodon $2001 ; 27: 328-32$.

12. Love RM. Enterococcus faecalis - a mechanism for its role in endodontic failure. Int Endod J 2001; 34:399-405.

13. Nair PNR. Pathobiology of the periapex. In: Cohen S, Burns RC, editors. Pathways of the pulp. St. Louis: Mosby, 2001.

14. Ørstavik D, Haapasalo M. Disinfection by endodontic irrigants and dressings of experimentally infected dentinal tubules. Endod Dent Traumatol 1990; 6:142-9.
15. Perez F, Rochdt T, Lodter JP, Calas P, Michel G. "In vitro" study of the penetration of three bacterial strains into root dentin. Oral Surg 1993; 76:97-103.

16. Sjögren V, Fidgor D, Spångberg L, Sundqvist G. The antimicrobial effect of calcium hydroxide as a short-term intracanal dressing. Int Endod J 1991; 24:119-25.

17. Sundqvist G. Taxonomy, ecology and pathogenicity of the root canal flora. Oral Surg 1994; 78:522-30.

18. Sydney GB. Identificação da microflora endodôntica após o preparo do canal radicular de dentes portadores de periodontite apical assintomática e o emprego de medicação de hidróxido de cálcio em diferentes tempos. [Thesis], São Paulo, Brazil: University of São Paulo, 1996.

19. Tronstad L. Clinical Endodontics. Thieme Medical Publishers: New York, 1991.

20. Tronstad L, Andersen JO, Hasselgren G, Kristerson L, Riis I. $\mathrm{pH}$ changes in dental tissues after root canal filling with calcium hydroxide. J Endodon 1981; 7:17-21.

Recebido para publicação em: 12/12/2002

Aceito após reformulações em: 20/03/2003

Correspondence:

Professor Carlos Estrela

ADDRESS:

Rua B-1, Quadra 6, Lote 2, Setor Bueno

Goiânia - GO - Brazil

CEP: 74.210-108, e-mail: estrela3@terra.com.br

Brazil

Phone: +55 (062) 251-0408 